\title{
Australian Journal of
}

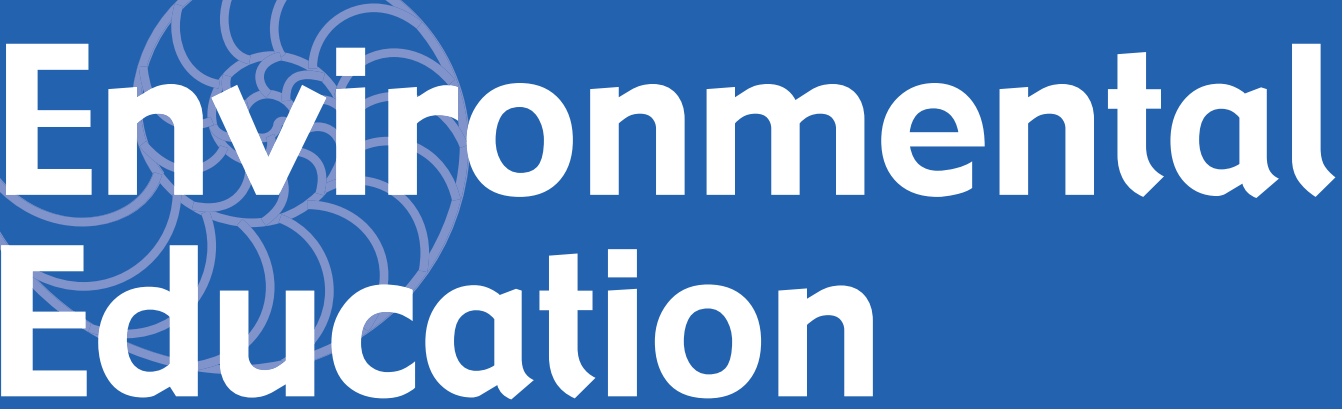

\section{Special Issue Guest Editors: Sally Birdsall and Peta White}

Special Issue: Making connections: Creating relationshipswith nonhuman nature, place and community
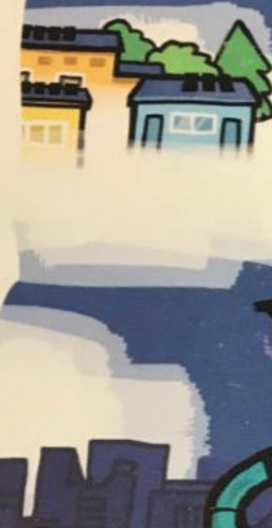

1
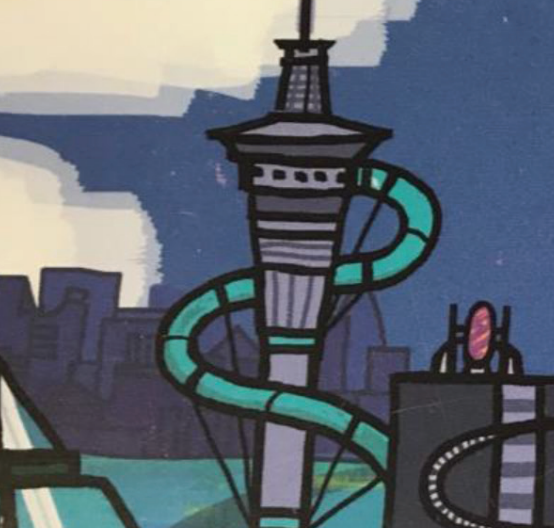

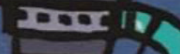
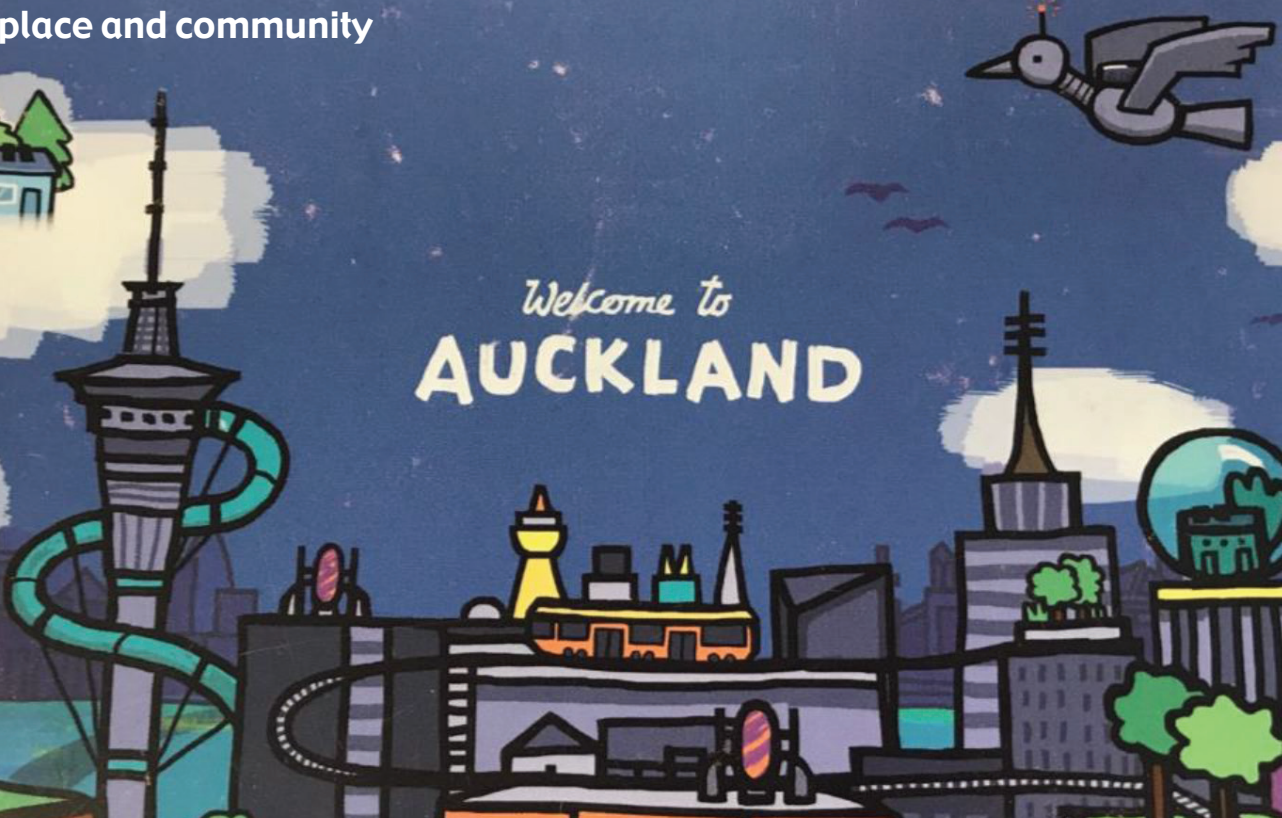

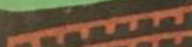

压
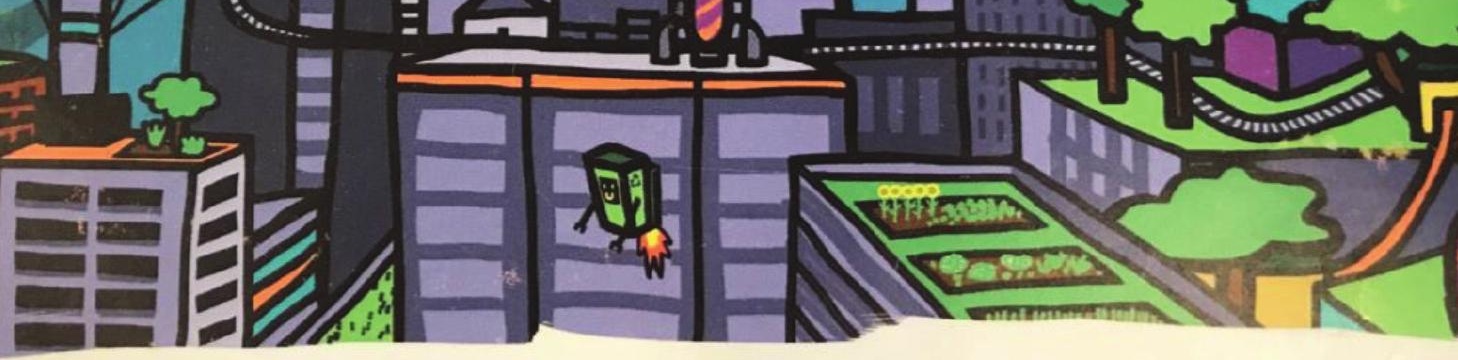
The Australian Journal of Environmental Education is an international refereed journal that publishes papers and reports on all aspects of environmental education. It is the journal of the Australian Association for Environmental Education. It is produced in order to present information and argument that will stimulate debate about educational strategies that enhance the kinds of awareness, understanding and actions that promote environmental and social justice. The journal is addressed to educators working in any educational setting where these matters are centrally or peripherally considered.

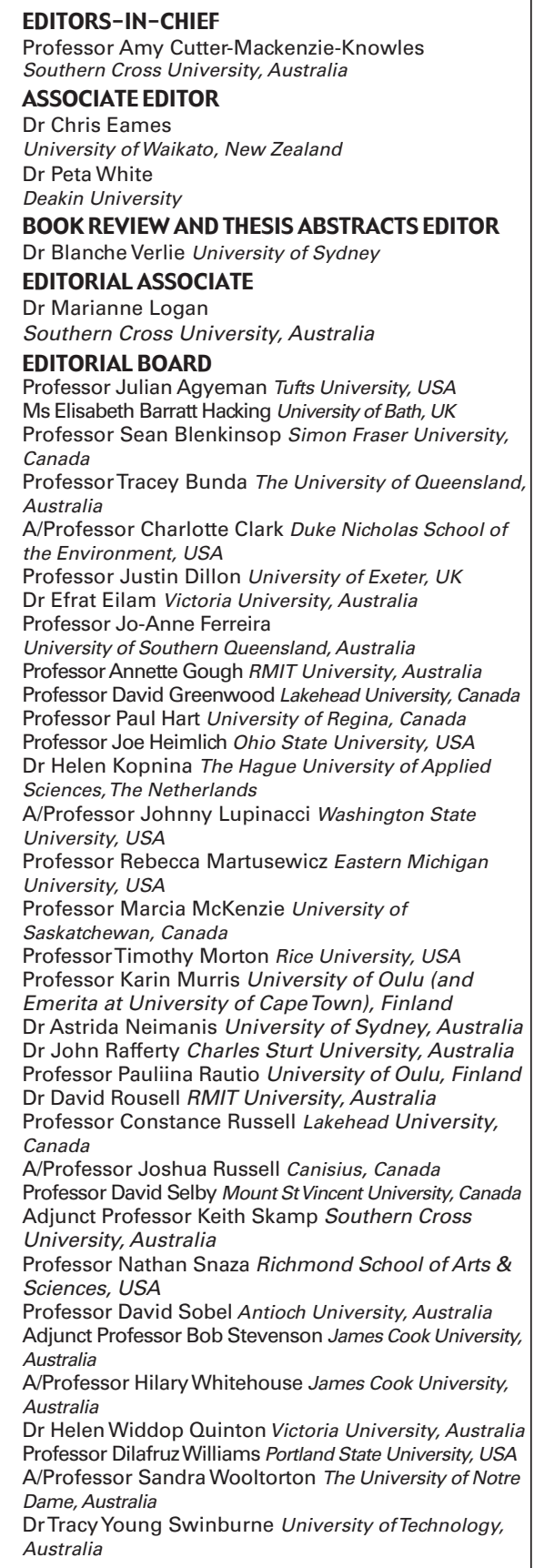

\section{EDITORS-IN-CHIEF}

Professor Amy Cutter-Mackenzie-Knowles

ASSOCIATE EDITOR

Dr Peta White

Deakin University

Dr Blanche Verlie University of Sydney

\section{EDITORIAL ASSOCIATE}

Southern Cross University, Australia

Professor Julian Agyeman Tufts University, USA Ms Elisabeth Barratt Hacking University of Bath, UK Canada

Australia

(

Professor Jo-Anne Ferreira

Professor David Greenwood Lakehead University, Canada

Professor Paul Hart University of Regina, Canada

University, USA

Professor Karin Murris University of Oulu (and

Emerita at University of Cape Town), Finland

Dimanis University of Sydney, Australia

Professor Pauliina Rautio University of Oulu, Finland

Dr David Rousell RMIT University, Australia

Professor Constance Russell Lakehead University,

Professor David Selby Mount St Vincent University, Canada

Adjunct Professor Keith Skamp Southern Cross

University, Australia

Sciences, USA

Professor David Sobel Antioch University, Australia Australia

A/Professor Hilary Whitehouse James Cook University,

Professor DilafruzWilliams Portland State University, USA

DrTracy Young Swinburne University of Technology,

Australia

\section{SUBSCRIPTION RATES 2020}

This journal is published triannually.

The institutional rates (excluding VAT) are:

$\begin{array}{lcc}\text { N America } & \text { Print and online } & \text { Electronic Only } \\ \text { UK and ROW } & 199 \mathrm{GBP} & 282 \mathrm{USD} \\ & 176 \mathrm{GBP}\end{array}$

EU subscribers (outside the UK) who are not registered for VAT should add VAT at their country's rate. VAT registered subscribers should provide their VAT registration number. Prices include delivery by air when appropriate. Japanese prices for institutions are available from Kinokuniya Company Ltd, P.O. Box 55, Chitose, Tokyo 156, Japan.

\section{Orders and subscription enquiries should be addressed to:}

Cambridge University Press, Journals Fulfillment Department, UPH, Shaftesbury Road, Cambridge CB2 $8 \mathrm{BS}, \mathrm{UK}$

Email: journals@cambridge.org

\section{Orders from $\mathbf{N}$ America should be addressed to:}

Cambridge University Press, 1 Liberty Plaza, New York, NY 10006, USA

Email: subscriptions_newyork@cambridge.org

The Australian Journal of Environmental Education and all other Cambridge Journals can be found at journals. cambridge.org/

Published by Cambridge University Press. All rights reserved. No part of this publication may be reproduced in any form or by any means, electronic, photocopying or otherwise, without permission in writing from Cambridge University Press.

Permission to copy (for users in the USA) is available from Copyright Clearance Center, www.copyright.com, email: info@copyright.com.

Illustration: Era Whittaker-Powley based on the ideas proposed by children in Lookout 


\section{Australian Journal of Environmental Education}

\section{Volume 36(3) 2020}

\section{Special Issue: Making connections: Creating relationships with nonhuman nature, place and community}

\section{Contents}

\section{EDITORIAL}

Making connections: creating relationships with nonhuman nature, place and community

Sally Birdsall and Peta White......

\section{Articles}

Where is the Love in Environmental Education Research? A Diffractive Analysis of Steiner, Ecosomaesthetics and Biophilia

Simone M. Blom, Claudio Aguayo and Teresa Carapeto

Entanglements of matter and meaning: The importance of the philosophy of Karen Barad for environmental education

Shae L. Brown, Lisa Siegel and Simone M. Blom

Lookout for learning: Exploring the links between drama and environmental education pedagogies

Susan J. Wake and Sally Birdsall.

Interpretations of sustainability beyond the middle class

Kim Beasy 246

\section{Book Reviews}

Education, Sustainability and the Ecological Social Imaginary: Connective Education and Global Change

Therese Ferguson. 264

Environmental education and ecotourism

Paul H. Mason 266

Ecological Economics

Anthony Kent

A Bat's End: The Christmas Island Pipistrelle and Extinction in Australia

Tessa Laird. 